\title{
Development of Validated Stability Indicating Method for Estimation of Vandetanib and Characterization of its Degradants by LC-ESI-MS
}

\author{
Vikrant Liladhar Salode ${ }^{1, *}$, Madhuri Deorao Game1, Gouri Vikrant Salode ${ }^{2}$, Sonali Suresh Gadge ${ }^{3}$ \\ ${ }^{1}$ Department of Pharmaceutical Chemistry, Vidyabharati College of Pharmacy, CK Naidu Road, Camp, Amravati, Maharashtra, INDIA. \\ ${ }^{2}$ Department of Pharmaceutics, PR Pote Patil College of Pharmacy, Kathora Road, Amravati, Maharashtra, INDIA. \\ ${ }^{3}$ Department of Quality Assurance, PR Patil Institute of Pharmacy, Talegaon (SP), Wardha, Maharashtra, INDIA.
}

\begin{abstract}
Aim: In the current study, stability indicating high performance liquid chromatography method (RP-HPLC) was developed and validated for the determination of Vandetanib, also its major degradants were identified and characterized by Liquid ChromatographyTandem Mass spectrophotometric method (LC-ESI-MS). Methods and Materials: This method was developed on Nucleosil 100-5, $C_{18}(250 \times 4.6 \mathrm{~mm}, 5 \mu \mathrm{m})$ column by using Methanol: Ammonium acetate buffer as Mobile phase in the ratio, 90:10 v/v, having flow rate of $1 \mathrm{ml} / \mathrm{min}$. The estimation was carried out at $249 \mathrm{~nm}$. Further Vandetanib was subjected to various stress condition like acidic, alkali, oxidative, thermal and photolytic degradation. The degradation pathways for major degradants were idenitifed. Results: The method was developed and validated for linearity, robustness, accuracy, precision, linear regression analysis data which indicates the good linear relationship, correlation coefficient was found 0.992 in the concentration range of $1-10 \mu \mathrm{g} / \mathrm{ml}$. In the stress results, the degradation of drug in alkaline, as well as acidic medium showed significantly. The product degradation was characterized by the LC-MS technique. Conclusion: The developed method was found to be rapid, sensitive, accurate, precise, and robust for the analysis of Vandetanib by which routine analysis of drugs can be done.
\end{abstract}

Key words: Mass Spectroscopy (MS), Vandetanib, High-Performance Liquid Chromatography (HPLC), Validation, Stress degradation.

\section{INTRODUCTION}

Vandetanib is chemically $N$ - $(4-$ bromo - 2 - flurophenyl) - 6 - methoxy - 7 - ((1-methylpiperidin-4-yl) methoxy) quinazolin - 4 - amine. It is used in the treatment of certain tumours of the thyroid gland. It blocks the activity of kinase and act as kinase inhibitor of a number of cell receptors, including the epidermal growth factor receptor (EGFR), vascular endothelial growth factor receptor (VEGFR), and the RET-tyrosinekinase. ${ }^{1}$ Literature survey shows that methods including UV-Vis spectoscropy, ${ }^{2}$ Spectrofluorimetry, ${ }^{3}$ bioanalytical HPLC, ${ }^{4}$ bioanalytical LC-MS ${ }^{5,6}$ have been published for the estimation of Vandetanib. This work describes development of simple, reliable
HPLC system and validation according to ICH guidelines for the determination of Vandetanib in bulk form as well as identification and characterization of major degradants by liquid chromatographictandem mass spectrometric method (LC-ESI-MS). Figure 1 presents structure of vandetanib.

\section{MATERIALS AND METHODS}

\section{Reagents and chemicals}

Methanol (HPLC grade), Acetonitrile (HPLC grade) were purchased from MERCK, Mumbai. Hydrochloric acid ( $\mathrm{HCl})$ Hydrogen peroxide $\left(\mathrm{H}_{2} \mathrm{O}_{2}\right)$ and sodium hydroxide $(\mathrm{NaOH})$,
Submission Date: 27-02-2021; Revision Date: 28-07-2021; Accepted Date: 10-09-2021.

DOI: 10.5530/ijper.56.1.27 Correspondence: Mr. VL Salode, Vidyabharti College of Pharmacy, C K Naidu Road, Camp, Amravati-444602, Maharashtra, INDIA. E-mail: e.vikrantsalode@ gmail.com

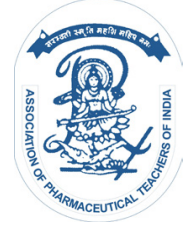

www.ijper.org 


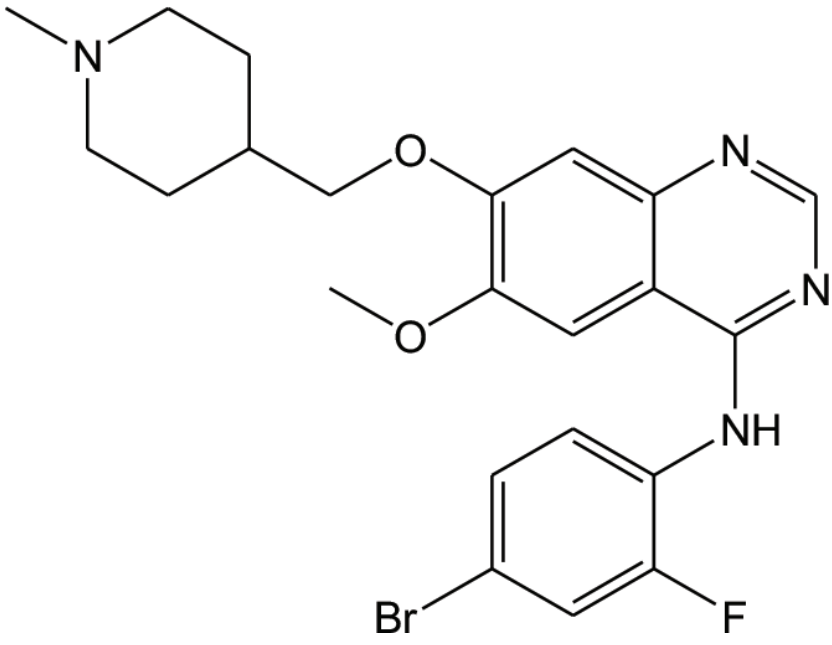

Figure 1: Chemical structure of Vandetanib.

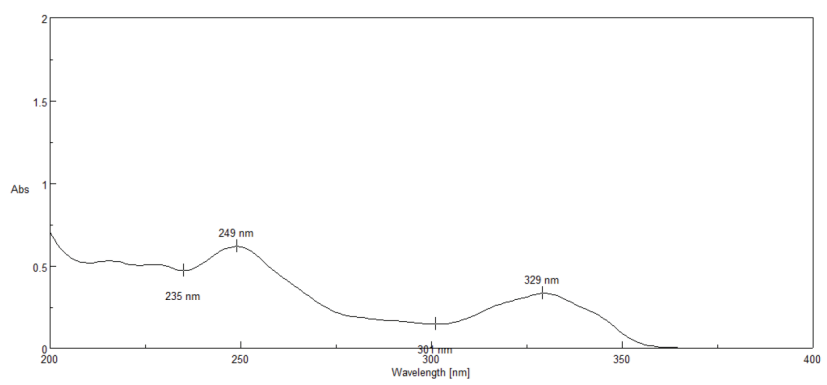

Figure 2: UV Spectra of Vandetanib $(10 \mu \mathrm{g} / \mathrm{ml})$.

Ammonium acetate AR grade were purchased from Loba Chemie Pvt. Ltd., Mumbai. HPLC water generated through PURELAB UHQ-II HPLC water purification system was used.

\section{Preparation of standard stock and buff}

The standard stock solution of $1000 \mu \mathrm{g} / \mathrm{ml}$ was prepared by dissolving $10 \mathrm{mg}$ of Vandetanib drug in $10 \mathrm{ml}$ of Methanol. From the above solution $1 \mathrm{ml}$ was pipette out and diluted to $10 \mathrm{ml}$ with mobile phase to get the concentration of $100 \mu \mathrm{g} / \mathrm{ml}$ of Vandetanib. Further dilutions were made in methanol. Buffer was prepared by dissolving $77.1 \mathrm{~g}$ of Ammonium acetate in water, $57 \mathrm{ml}$ of glacial acetic acid and diluted with water to $1000 \mathrm{ml}$.

\section{Selection of wavelength}

Further dilutions were made from the standard stock solution $(1000 \mu \mathrm{g} / \mathrm{ml})$ using methanol and scanned using visible range of 200- $400 \mathrm{~nm}$ using UV spectrophotometer, spectra was obtained and maximum

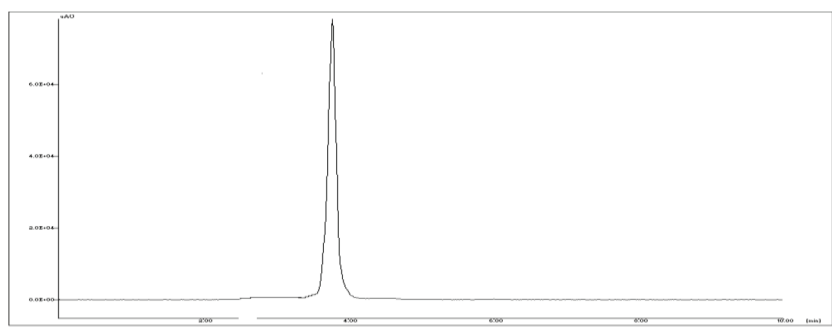

Figure 3: Chromatogram of Standard Vandetanib $(10 \mu \mathrm{g} / \mathrm{ml})$.

wavelength was found to be at $249 \mathrm{~nm}$. A UV spectrum of Vandetanib is given in Figure 2.

\section{Chromatographic conditions}

HPLC system used was JASCO system equipped with model PU 2080 Plus pump, Rheodyne sample injection port $(20 \mu \mathrm{l})$, JASCO MD2010 Plus detector and Borwin chromatography software (version 1.5). A chromatographic column used was Nucleosil 100-5 $\mathrm{C}_{18}(250 \times 4.6 \mathrm{~mm}, 5 \mu \mathrm{m})$ operated at flow rate of $1.0 \mathrm{ml} / \mathrm{min}$ using Methanol: Ammonium acetate Buffer in the ratio of $90: 10 \mathrm{v} / \mathrm{v}$ as mobile phase and wavelength detection at $249 \mathrm{~nm}$. Figure 3 represents standard chromatogram of $10 \mathrm{ppm}$ of Vandetanib.

\section{Stress Degradation Studies of Bulk Drug}

Stress degradation studies were performed under certain conditions like base, acid, neutral hydrolysis, oxidation, Photolysis and dry heat. Two samples were prepared (Blank and of Vandetanib RS) for each study. The blank and the drug solution were subjected to stress in the same manner. Photolytic degradation and dry heat were performed in solid state. A summary of stress degradation study of drug Vandetanib is given in Table 1.

\section{Alkaline hydrolysis}

Standard solution of Vandetanib $(1000 \mu \mathrm{g} / \mathrm{ml}), 1 \mathrm{ml}$ was mixed with $1 \mathrm{ml}$ of $1 \mathrm{~N} \mathrm{NaOH}$ and the solution was kept for overnight in dark place. Solution was neutralized with $1 \mathrm{~N} \mathrm{HCl}$ and made volume to $10 \mathrm{ml}$. $1 \mathrm{ml}$ of resulting solution was diluted to $10 \mathrm{ml}$ with mobile phase $(10 \mu \mathrm{g} / \mathrm{ml})$ and it was injected under optimized chromatographic condition. After alkaline degradation, Vandetanib showed one peak of degradation product at $\mathrm{R}_{t} 5.91$. The percent recovery of Vandetanib was $67.52 \%$ (Figure 4)

\section{Acidic hydrolysis}

Standard solution of Vandetanib $(1000 \mu \mathrm{g} / \mathrm{ml}), 1 \mathrm{ml}$ was added to $1 \mathrm{ml}$ of methanolic $1 \mathrm{~N} \mathrm{HCl}$ and the resulting solution was kept for overnight in dark place. Solution was neutralized with $1 \mathrm{~N} \mathrm{NaOH}$, Volume made to $10 \mathrm{ml}$ and the resulting solution, $1 \mathrm{ml}$ was 


\begin{tabular}{|c|c|c|c|}
\hline $\begin{array}{l}\text { Sr. } \\
\text { No. }\end{array}$ & $\begin{array}{l}\text { Stress Degradation } \\
\text { Condition }\end{array}$ & $\%$ Recovery & $\begin{array}{c}\text { R.T. of } \\
\text { degraded } \\
\text { products }\end{array}$ \\
\hline 1 & $\begin{array}{c}\text { Base (1 N NaOH, kept } \\
\text { for overnight) }\end{array}$ & 67.52 & VD1 -5.91 \\
\hline 2 & $\begin{array}{c}\text { Acid (1 } \mathrm{N} \mathrm{HCl} \text {, Kept for } \\
\text { overnight) }\end{array}$ & 85.73 & VD1 -5.92 \\
\hline 3 & $\begin{array}{c}\mathrm{H}_{2} \mathrm{O}_{2}, 30 \% \text { (Kept for } \\
\text { overnight) }\end{array}$ & 87.52 & \\
\hline 4 & Dry Heat $\left(80^{\circ} \mathrm{C}\right.$ for $\left.6 \mathrm{hr}\right)$ & 98.95 & \\
\hline 5 & $\begin{array}{c}\text { Photo stability [UV, } 200 \\
\text { watt hrs/square meter } \\
\text { Florescence, } 1.2 \text { million } \\
\text { Lux. Hrs] }\end{array}$ & 98.53 & \\
\hline
\end{tabular}

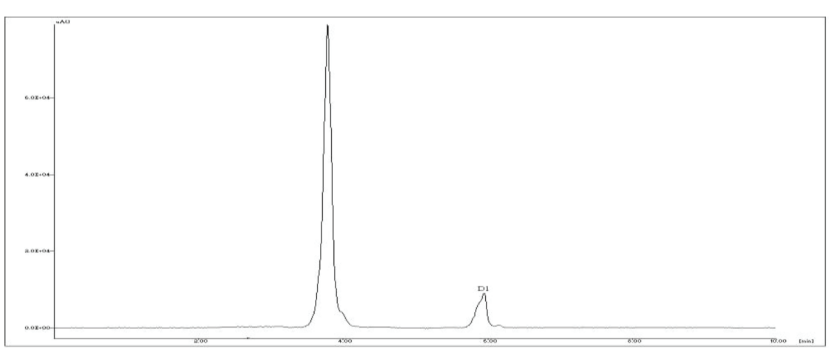

Figure 4: Chromatogram of Vandetanib $(10 \mu \mathrm{g} / \mathrm{ml})$ after alkaline hydrolysis.

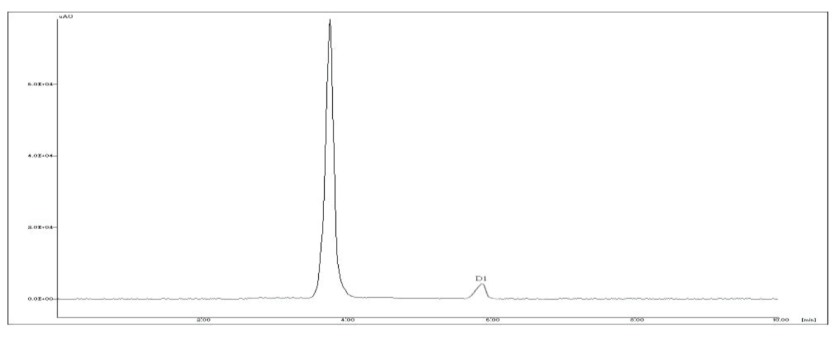

Figure 5: Chromatogram of Vandetanib $(10 \mu \mathrm{g} / \mathrm{ml})$ after acid degradation.

diluted to $10 \mathrm{ml}$ with mobile phase $(10 \mu \mathrm{g} / \mathrm{ml})$ and then it was injected under optimized chromatographic condition. After acid hydrolysis, Vandetanib showed one peak of degraded product (at RT 5.92) with 85.73 $\%$ recovery (Figure 5 ).

\section{Oxidative Degradation}

Standard solution of Vandetanib $(1000 \mu \mathrm{g} / \mathrm{ml}), 1 \mathrm{ml}$ was added to $30 \%$ solution of Hydrogen peroxide $(1 \mathrm{ml})$ and the solution was allowed to stand for overnight in dark place. Volume made to $10 \mathrm{ml}$ and the resulting solution, $1 \mathrm{ml}$ was diluted to $10 \mathrm{ml}$ with mobile phase $(10 \mu \mathrm{g} / \mathrm{ml})$ and then it was injected under optimized chromatographic condition. In the

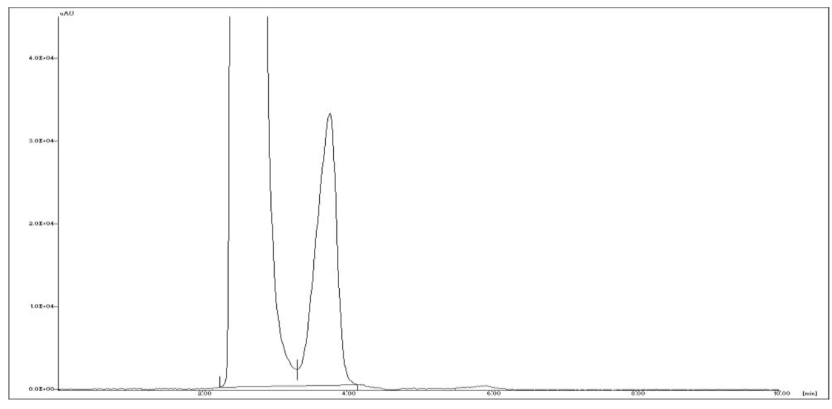

Figure 6: Chromatogram of Vandetanib $(10 \mu \mathrm{g} / \mathrm{ml})$ after oxidation.

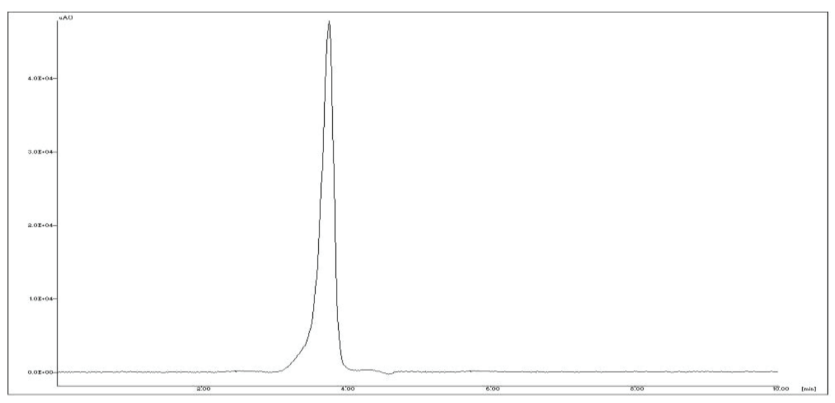

Figure 7: Chromatogram of Vandetanib $(10 \mu \mathrm{g} / \mathrm{ml})$ after exposing to dry heat.

oxidative condition, percent recovery obtained for Vandetanib was $87.52 \%$ with no peak of degradation observed in chromatograph (Figure 6).

\section{Degradation under dry heat}

In the dry heat studies, drug sample was kept in oven $\left(80^{\circ} \mathrm{C}\right)$ for $6 \mathrm{hr}$. After specified period of time, sample was withdrawn and solution was prepared having concentration of $100 \mu \mathrm{g} / \mathrm{ml}$ same as standard solution preparation. The resulting solution, $1 \mathrm{ml}$ was further diluted to $10 \mathrm{ml}$ with mobile phase $(10 \mu \mathrm{g} / \mathrm{ml})$ and it was injected under optimized chromatographic condition. In the dry heat degradation condition, percent recovery obtained for Vandetanib was $98.95 \%$ with no peak of degradation product (Figure 7).

\section{Photo-degradation studies}

Photolytic studies were performed by the exposure of drug to UV light up to 200 watt hours/square meter and subsequently to cool fluorescent light to achieve an illumination of 1.2 million Lux hr. The sample withdrawn after exposure and processed as per standard solution preparation procedure mentioned under 6.5 to get $100 \mu \mathrm{g} / \mathrm{ml}$ as solution concentration. The $1 \mathrm{ml}$ of resulting solution was diluted with mobile phase to $10 \mathrm{ml}(10 \mu \mathrm{g} / \mathrm{ml})$ and then was injected under optimized chromatographic condition. ${ }^{7}$ The photo degradation 


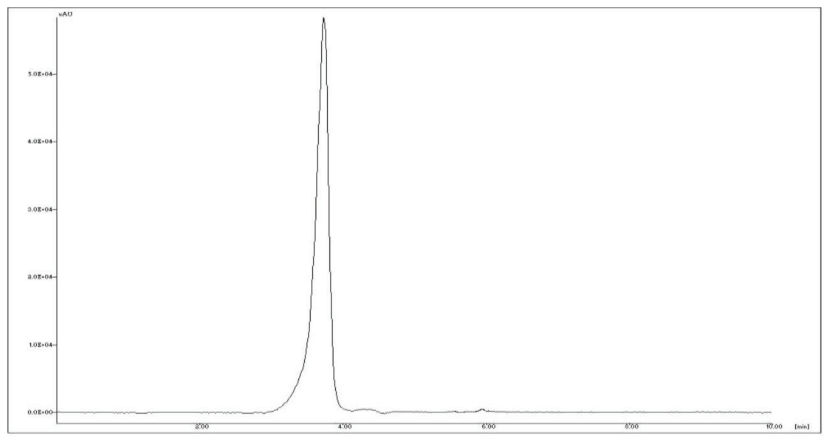

Figure 8: Chromatogram of Vandetanib $(10 \mu \mathrm{g} / \mathrm{ml})$ after photo degradation.

study for UV light and Fluorescence light, Vandetanib showed no peak of degraded product with $98.53 \%$ recovery (Figure 8).

\section{Identification, Characterization and Prediction of Degradation Product by LC-MS}

Forced degradation studies were performed as per ICH guidelines Q1A (R2). All solutions and stressed solid samples were fortified, wrapped with aluminum foil, refrigerated at $-4^{\circ} \mathrm{C}$ for analysis. The LC-MS study was performed for standard drug as well as for forced degradation samples of drug for acid, alkali and oxidation under which degradation was observed during development of stability indicating assay method.

Successful separation of one degradation product under acidic as well as alkali condition was observed by high performance liquid chromatography (HPLC) using Zorbax Eclipise XDB-C ${ }_{18}(150 \mathrm{~mm} \times 3.0 \mathrm{~mm}$, $3.55 \mu \mathrm{m})$ analytical column. It was identified and characterized by liquid chromatography-electrospray ionization mass spectrometry (LC-ESI/MS) with accurate mass measurements up to four decimal.

\section{Mass Spectroscopy Conditions}

Mass Spec parameters were optimized for drugs to get highest intensity while tuning for scan to identify the $[\mathrm{M}+\mathrm{H}]$. Quantification was achieved with MS detection in positive ion mode for the drugs and its degrading products. Agilent LC-MS Q - TOF (6200 series TOF/6500 series) (5301 Stevens Creek Blvd, Santa Clara, CA 95051, United States) equipped with a dual AJS ESI with improved sensitivity [AJS - ESI: Agilent Jet Stream Electro spray Ionizer] and Q-TOF B.05.01 software version. The Min Range and Max Range in acquisition mode was set to 60 and 1000, respectively with scan rate of 2 spectra /sec.

Chromatograph of Vandetanib subjected to Acidic stress is given in Figure 9. LC-MS Spectrum of Vandetanib

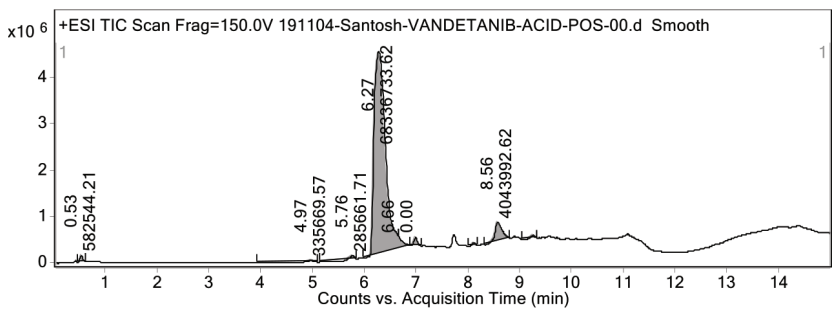

Figure 9: Chromatograph of Vandetanib subjected to Acidic stress.

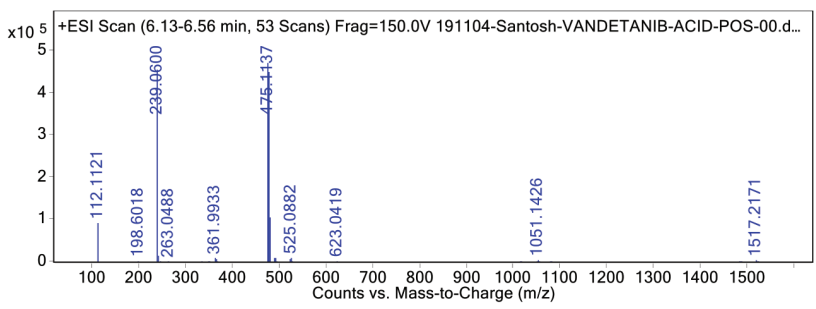

Figure 10: LC-MS Spectrum of Vandetanib from acidic stress sample (Retention Time - 6.27 min).

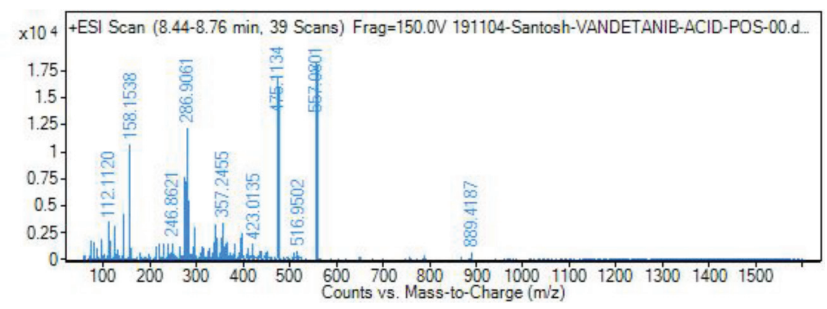

Figure 11: LC -MS Spectrum of VD1 of Vandetanib acid stress sample (Retention Time - $8.56 \mathrm{~min}$ ).

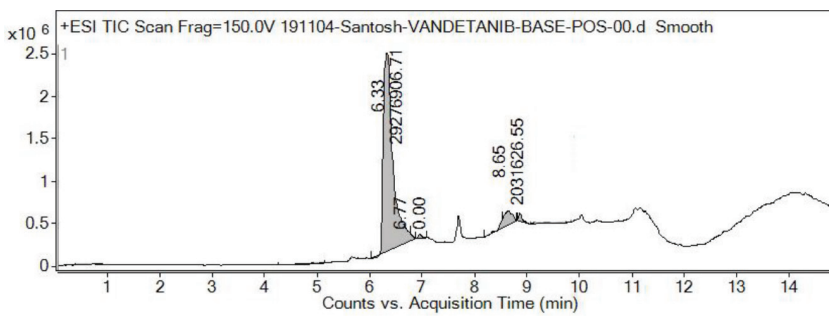

Figure 12: Chromatograph of Vandetanib subjected to Alkali stress.

and its degradant VD1 from acidic stress sample is given in Figure 10 and Figure 11. Chromatograph of Vandetanib subjected to Alkali stress is given in Figure 12. LC-MS Spectrum of Vandetanib and its degradant VD1 from acidic stress sample is given in Figure 13 and Figure 14. Probable degradation pathway of Vandetanib under Acid/Alkali stress sample is presented in Figure 15.

\section{Analytical Method Validation}

The method that was developed, validated as per ICH Q2 (R1) guidelines. ${ }^{8}$ 


\section{Specificity}

The method specificity was determined by peak purity profiling studies. The values of peak purity were found to be more than 998, indicating that there is no disturbance of any other degradation product peak, matrix and impurity.

\section{Range and Linearity}

Further dilutions were made with mobile phase from the Vandetanib standard stock solution $(100 \mu \mathrm{g} / \mathrm{ml})$ to make solutions of six different concentrations. These six solutions per concentration were injected. The linearity i.e. relationship between peak area $\mathrm{v} / \mathrm{s}$ concentration was determined over the concentration

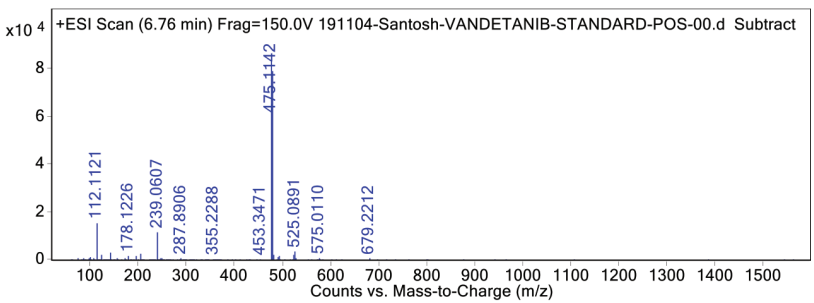

Figure 13: LC-MS Spectrum of Vandetanib from alkali stress sample (Retention Time - $6.33 \mathrm{~min}$ ).

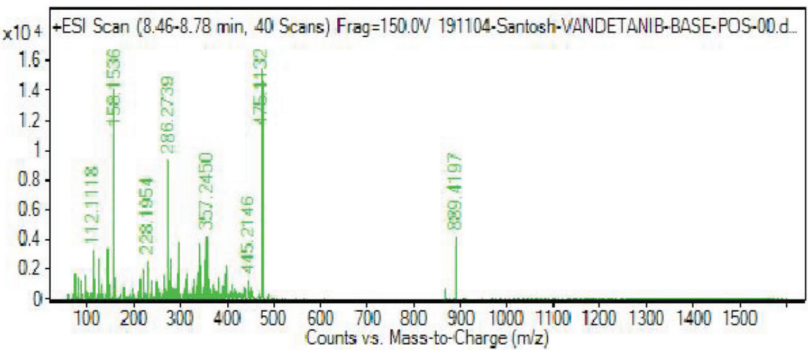

Figure 14: LC -MS Spectrum of VD1 of Vandetanib alkali stress sample (Retention Time - $8.65 \mathrm{~min}$ ). range of $1-10 \mu \mathrm{g} / \mathrm{ml}$. The results are shown in Table 2. The graph was plotted against the peak area and corresponding concentrations for obtaining the calibration curve. The results found linear with regression equation of $\mathrm{Y}=85361 \mathrm{X}+46194$ and correlation coefficient of 0.992 .

\section{Precision}

The precision studies were carried out for the developed method by performing Inter-day and Intra-day variation studies. Intraday studies were performed by analyzing the 3 replicates of 3 different concentrations $(2,4,5$ $\mu \mathrm{g} / \mathrm{ml}$ ) of Vandetanib in a day and percentage RSD was calculated. Inter day studies were performed by analyzing<smiles>COc1cc2c(Nc3ccc(Br)cc3F)ncnc2cc1OCC1CCN(C)CC1</smiles>

$\mathrm{M}+\mathrm{H}$ Peak $\mathrm{m} / \mathrm{z}=475.1146$

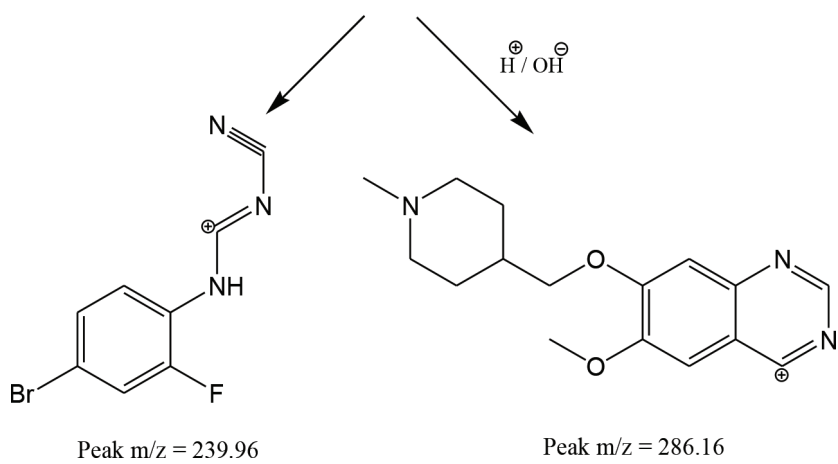

Figure 15: Probable degradation pathway of Vandetanib under Acid/Alkali stress sample.

\begin{tabular}{|c|c|c|c|c|c|c|}
\hline \multirow{3}{*}{ Replicates } & \multicolumn{6}{|c|}{ Concentrations of Vandetanib } \\
\hline & $1 \mu \mathrm{g} / \mathrm{ml}$ & $2 \mu \mathrm{g} / \mathrm{ml}$ & $3 \mu \mathrm{g} / \mathrm{ml}$ & $4 \mu \mathrm{g} / \mathrm{ml}$ & $5 \mu \mathrm{g} / \mathrm{ml}$ & $10 \mu \mathrm{g} / \mathrm{ml}$ \\
\hline & \multicolumn{6}{|c|}{ Peak Area } \\
\hline 1 & 124015.4 & 212342.4 & 294585 & 368249 & 529420.8 & 888174 \\
\hline 2 & 127300.5 & 221236.4 & 289042 & 370148 & 516344.1 & 890665 \\
\hline 3 & 130291.3 & 220485 & 279026 & 379630 & 516875.4 & 879632 \\
\hline 4 & 126550.8 & 216294.5 & 291468 & 370098 & 523445.7 & 874635 \\
\hline 5 & 130113.5 & 215782.5 & 293213 & 359237 & 517796.4 & 905476 \\
\hline 6 & 129052.7 & 215484.8 & 284350 & 366922 & 522145.5 & 887624 \\
\hline Mean & 127887.4 & 216937.59 & 288614 & 369047.2 & 521004.6 & 887700.9 \\
\hline Std. Dev. & 2417.24 & 3347.76 & 5920.26 & 6568.425 & 5042.95 & 10590.56 \\
\hline \%RSD & 1.89 & 1.543 & 2.05 & 1.779 & 0.967 & 1.19 \\
\hline
\end{tabular}




\begin{tabular}{|c|c|c|c|c|c|c|c|c|}
\hline \multicolumn{7}{|c|}{ Table 3: Intra-day precision study Vandetanib. } \\
\hline $\begin{array}{c}\text { Theorotical Conc } \\
(\mathbf{m c g} / \mathbf{m l})\end{array}$ & Area & Slope & Intercept & $\begin{array}{c}\text { Practical } \\
\text { Conc }\end{array}$ & \% assay & Avg* & SD & RSD \\
\hline 2 & 215168.976 & 85361 & 46194 & 1.980 & 98.977 & & & \\
\hline 2 & 218398.764 & 85361 & 46194 & 2.017 & 100.869 & 100.245 & 1.098 & 1.095 \\
\hline 2 & 218433.365 & 85361 & 46194 & 2.018 & 100.889 & & & \\
\hline 4 & 389527.102 & 85361 & 46194 & 4.022 & 100.553 & & & \\
\hline 4 & 384547.19 & 85361 & 46194 & 3.964 & 99.095 & 99.728 & 0.748 & 0.750 \\
\hline 4 & 386051.63 & 85361 & 46194 & 3.981 & 99.535 & & & \\
\hline 5 & 475045.778 & 85361 & 46194 & 5.024 & 100.480 & & & \\
\hline 5 & 474626.91 & 85361 & 46194 & 5.019 & 100.381 & 100.149 & 0.489 & 0.489 \\
\hline 5 & 471236.962 & 85361 & 46194 & 4.979 & 99.587 & & & \\
\hline
\end{tabular}

*Average of three determinations

\begin{tabular}{|c|c|c|c|c|c|c|c|c|}
\hline $\begin{array}{l}\text { Theo. Conc } \\
\text { (mcg/ml) }\end{array}$ & Area & Slope & Intercept & $\begin{array}{l}\text { Practical } \\
\text { Conc }\end{array}$ & $\%$ assay & Avg* & SD & RSD \\
\hline 2 & 217342.4 & 85361 & 46194 & 2.005 & 100.250 & & & \\
\hline 2 & 216236.4 & 85361 & 46194 & 1.992 & 99.602 & 99.866 & 0.340 & 0.340 \\
\hline 2 & 216485.0 & 85361 & 46194 & 1.995 & 99.748 & & & \\
\hline 4 & 390699.2 & 85361 & 46194 & 4.036 & 100.897 & & & \\
\hline 4 & 386868.4 & 85361 & 46194 & 3.991 & 99.775 & 100.373 & 0.565 & 0.563 \\
\hline 4 & 389164.95 & 85361 & 46194 & 4.018 & 100.447 & & & \\
\hline 5 & 469877.13 & 85361 & 46194 & 4.963 & 99.269 & & & \\
\hline 5 & 470860.03 & 85361 & 46194 & 4.975 & 99.499 & 99.599 & 0.391 & 0.392 \\
\hline 5 & 473129.48 & 85361 & 46194 & 5.002 & 100.031 & & & \\
\hline
\end{tabular}

*Average of three determinations

the 3 replicates of different concentrations of Vandetanib on three consecutive days and percentage RSD were calculated. The results for Inter-day and Intra day variation studies are shown in Table 3 and Table 4.

\section{LOD (Limit of Detection) and LOQ (Limit of Quantification)}

Limit of detection and Limit of Quantitation was calculated from the linearity data by using the formula LOQ $=10 \sigma / S$ and LOD $=3.3 \sigma / S$ where, $\sigma=S D$ of the Y-intercept and $S=$ Slope of the calibration curve. The LOD and LOQ were found to be 0.146 and 0.443 . The formulation analysis of Vandetanib is shown in Table 5.

\section{Assay}

\section{Preparation of Blend (Synthetic mixture)}

Assay of Vandetanib was done by spike blend method due to unavailability of its marketed preparation. $300 \mathrm{mg}$ of Vandetanib was mixed with equal amounts $(100 \mathrm{mg})$

\begin{tabular}{|c|c|c|c|}
\hline \multicolumn{4}{|c|}{ Table 5: Results of formulation analysis of } \\
Vandetanib (Assay). \\
\hline Sr. No. & Area & $\begin{array}{c}\text { Concentration } \\
(\mu \mathrm{g} / \mathrm{ml})\end{array}$ & $\%$ Recovery \\
\hline 01 & 216685.6 & 1.997 & 99.865 \\
\hline 02 & 217752.4 & 2.010 & 100.490 \\
\hline 03 & 219831.9 & 2.034 & 101.708 \\
\hline 04 & 218046.5 & 2.013 & 100.662 \\
\hline 05 & 214913.3 & 1.977 & 98.827 \\
\hline 06 & 215739.4 & 1.986 & 99.311 \\
\hline Mean & 217161.517 & 2.003 & 100.144 \\
\hline S.D & 1764.465 & 0.021 & 1.034 \\
\hline$\%$ RSD & 0.813 & 1.032 & 1.032 \\
\hline
\end{tabular}

of starch and lactose to make $500 \mathrm{mg}$ of spike blend. The contents of spike blend were properly mixed. Assay was performed on blend of bulk drug with excipients. A quantity of synthetic mixture (Blend) and equal amount of $10 \mathrm{mg}$ of Vandetanib was mixed with $5 \mathrm{ml}$ 


\begin{tabular}{|c|c|c|c|c|c|}
\hline Level & $\begin{array}{c}\text { Sample Conc. } \\
(\mu \mathrm{g} / \mathrm{ml})\end{array}$ & $\begin{array}{c}\text { Std Conc. } \\
(\mu \mathrm{g} / \mathrm{ml})\end{array}$ & Area & $\begin{array}{c}\text { Amount } \\
\text { Recovered }\end{array}$ & $\begin{array}{c}\% \text { recovery } \\
\text { (Mean } \pm \% R S \text { ) }\end{array}$ \\
\hline \multirow{3}{*}{$50 \%$} & \multirow{3}{*}{2} & \multirow{3}{*}{1} & 294939.4 & 2.914 & \multirow{3}{*}{$100.427 \pm 0.920$} \\
\hline & & & 296025.3 & 2.927 & \\
\hline & & & 296473.7 & 2.932 & \\
\hline \multirow{3}{*}{$100 \%$} & \multirow{3}{*}{2} & \multirow{3}{*}{2} & 378524.2 & 3.893 & \multirow{3}{*}{$99.199 \pm 0.498$} \\
\hline & & & 379621.8 & 3.906 & \\
\hline & & & 380180.9 & 3.913 & \\
\hline \multirow{3}{*}{$150 \%$} & \multirow{3}{*}{2} & \multirow{3}{*}{3} & 461790.6 & 4.869 & \multirow{3}{*}{$99.982 \pm 1.609$} \\
\hline & & & 466593.8 & 4.925 & \\
\hline & & & 469988.2 & 4.965 & \\
\hline
\end{tabular}

methanol in a $10 \mathrm{ml}$ volumetric flask. The resulting mixture was then ultra sonicated for $10 \mathrm{~min}$ and the resulting sample stock solution was filtered with Whatman filter paper 41 and volume was made up with the methanol to make the concentration of $1000 \mu \mathrm{g} / \mathrm{ml}$. Final solution of concentration $2 \mu \mathrm{g} / \mathrm{ml}$ was made in mobile phase. Procedure was repeated for six times. Percentage assay was determined by extrapolation of peak area from linearity equation.

\section{Accuracy}

Recovery studies were performed for checking the accuracy of the developed method. For this purpose the standard drug was added to the sample at three different levels 50, 100 and $150 \%$. The concentration of sample solution, $2 \mu \mathrm{g} / \mathrm{ml}$ was chosen as basic concentration. These solutions were injected three times in stabilized chromatographic conditions to obtain the chromatograms. The Vandetanib drug concentrations were calculated by using linearity equation. The results are shown in Table 6.

\section{Robustness}

Robustness of the developed method was checked by altering the mobile phase composition, flow rate $( \pm 0.05 \mathrm{ml} / \mathrm{min})$, wavelength detection $( \pm 1 \mathrm{~nm})$ under certain conditions and the effect on the area was noted. The robustness of the method was performed by alterations done in the analytical parameters, but the peak area remained unaffected that indicates that the method is robust.

\section{CONCLUSION}

A simple, rapid, precise, accurate and sensitive high performance liquid chromatographic (HPLC) method was developed and validated for the analysis of Vandetanib in bulk and tablet dosage form. Separation was done on
Nucleosil 100-5 $\mathrm{C}_{18}(250 \times 4.6 \mathrm{~mm}, 5 \mu \mathrm{m})$ column. Methanol: Ammonium acetate Buffer was used as mobile phase in the ratio of $90: 10 \mathrm{v} / \mathrm{v}$ and at flow rate of $1 \mathrm{ml} / \mathrm{min}$ and maximum wavelength was detected at $249 \mathrm{~nm}$. The retention time (RT) of drug Vandetanib was found to be $3.717 \pm 0.034 \mathrm{~min}$. The developed method was validated for linearity, range, accuracy, robustness, method precision (intraday and inter day). The linear regression analysis data indicated that a good linear relationship showed in the concentration range of $1-10 \mu \mathrm{g} / \mathrm{ml}$. The correlation coefficient $\left(\mathrm{R}^{2}\right)$ was found to be 0.992 . The $\%$ assay was found to be $100.144 \pm 1.032$. The developed method can be adopted for routine analysis of drug in bulk and pharmaceutical dosage form.

\section{ACKNOWLEDGEMENT}

The authors are thankful to Vidyabharati College of Pharmacy, Amravati for providing research facility.

\section{CONFLICT OF INTEREST}

The authors declare no conflicts of interest.

\section{ABBREVIATIONS}

HPLC: High Performance Liquid Chromatography; ICH: International Conference on Harmonization; LOD: Limit of Detection; LOQ: Limit of Quantification; HCl: Hydrochloric acid; $\mathbf{N a O H}$ Sodium Hydroxide; $\mathbf{H}_{2} \mathbf{O}_{2}$ : Hydrogen Peroxide; RSD: Relative Standard Deviation; SD: Standard Deviation.

\section{REFERENCES}

1. Fallahi P, Ferrari SM, Baldini E, Biricotti M, Ulisse S, Materazzi G, Miccoli P, Antonelli A. The safety and efficacy of vandetanib in the treatment of progressive medullary thyroid cancer. Expert Rev Anticancer Ther. 
2016;16(11):1109-18. doi: 10.1080/14737140.2016.1238764, PMID 27650489.

2. Khandare B, Dudhe PB, Upasani S, Dhoke M. Spectrophotometric determination of vandetanib in bulk by area under curve and first order derivative methods. Int J PharmTech Res. 2019;12(2):103-10. doi: 10.20902/ IJPTR.2019.120202

3. Darwish HW, Bakheit AH. A New spectrofluorimetric assay method for vandetanib in tablets, plasma and urine. Trop J Pharm Res. 2016;15(10):2219-25. doi: 10.4314/tjpr.v15i10.21.

4. Lin H, Cui D, Cao Z, Bu Q, Xu Y, Zhao Y. Validation of a high-performance liquid chromatographic ultraviolet detection method for the quantification of vandetanib in rat plasma and its application to pharmacokinetic studies. J Cancer Res Ther. 2014;10(1):84-8. doi: 10.4103/0973-1482.131393, PMID 24762492.
5. Amer SM, Kadi AA, Darwish HW, Attwa MW. Liquid chromatography tandem mass spectrometry method for the quantification of vandetanib in human plasma and rat liver microsomes matrices: metabolic stability investigation. Chem Cent J. 2017;11(1):45. doi: 10.1186/s13065-017-0274-4, PMID 29086823.

6. Bai F, Johnson J, Wang F, Yang L, Broniscer A, Stewart CF. Determination of vandetanib in human plasma and cerebrospinal fluid by liquid chromatography electrospray ionization tandem mass spectrometry(LC-ESI-MS/MS). J Chromatogr B Analyt Technol. Life Sci. 2011;879(25):2561-66.

7. $\mathrm{ICH}$ Q1. A (R2), Stability testing of new drug substances and products. Geneva; 2003. p. 1-22.

8. $\mathrm{ICH}$. Validation of analytical procedure text and methodology, International Conference on Harmonization, Geneva 2005. Vol. Q2(R1). p. 1-13.

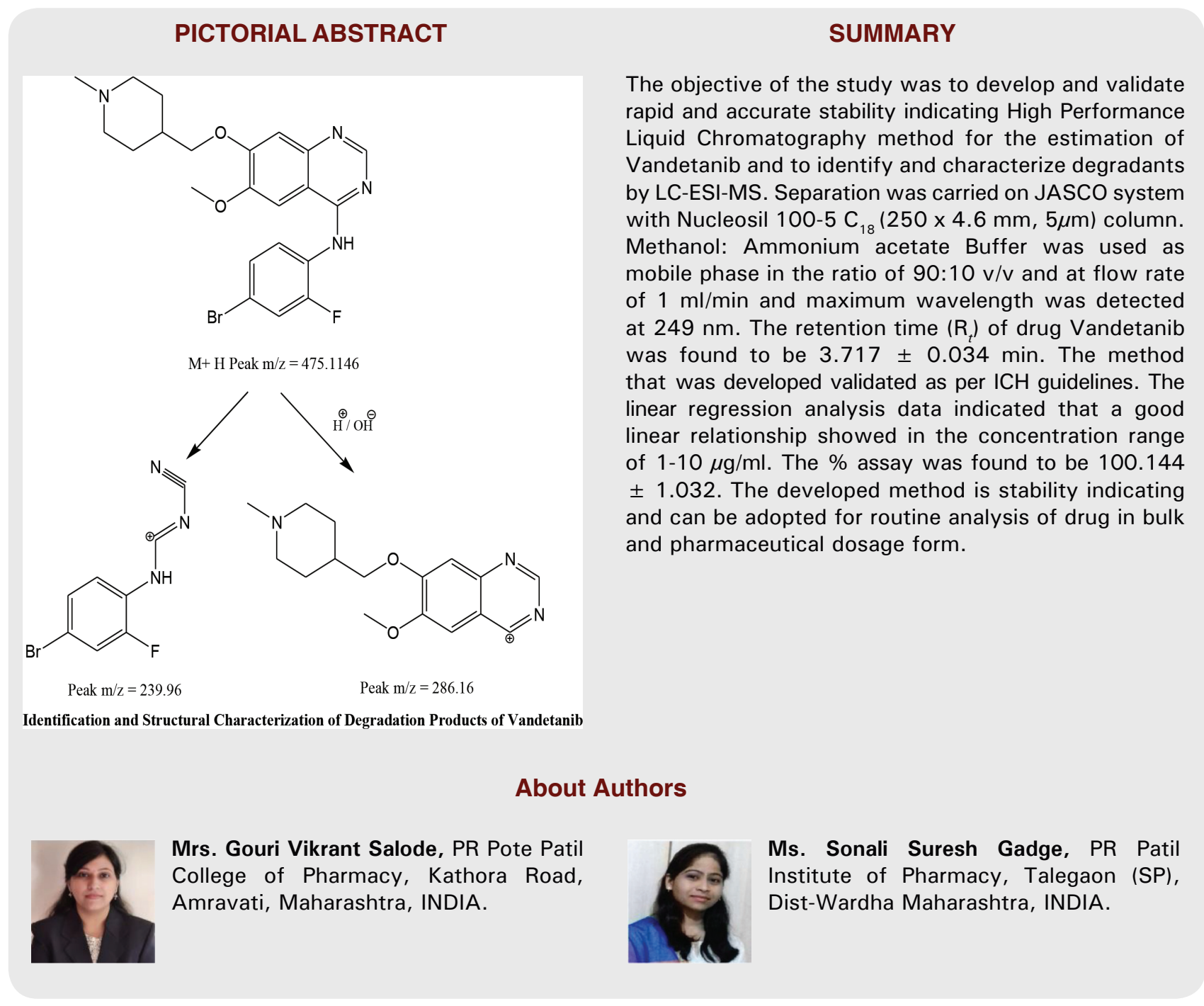

Cite this article: Salode VL, Game MD, Salode GV, Gadge SS. Development of Validated Stability Indicating Method for Estimation of Vandetanib and Characterization of its Degradants by LC-ESI-MS. Indian J of Pharmaceutical Education and Research. 2022;56(1):232-9. 